\title{
It Started with the Arts and Now It Concerns All Sectors: The Case of Smart, a Cooperative of 'Salaried Autonomous Workers'
}

\author{
Annalisa Murgia and Sarah de Heusch
}

\section{INTRODUCTION}

In the past few decades there have been a variety of attempts to interpret the processes of flexibilisation and individualisation of work (Beck 1992; Sennett 1998; Boltanski and Chiapello 1999; Bauman 2000). Cultural and creative industries are an emblematic case for understanding these phenomena, firstly, because they have been early adopters of flexible working arrangements and, secondly, because they embody the ambivalence of the flexibilisation and individualisation of work, which may increase not only the autonomy and degrees of freedom for workers but also their personal exposure to risk and precariousness. Much sociological

\footnotetext{
A. Murgia $(\bowtie)$

Department of Social and Political Sciences, University of Milan, Milan, Italy e-mail: annalisa.murgia@unimi.it

S. de Heusch

Public Affairs Officer, Smart, Brussels, Belgium

e-mail: sarah.de.heusch@smart.coop

(C) The Author(s) 2020

S. Taylor, S. Luckman (eds.), Pathways into Creative

Working Lives, Creative Working Lives, https://doi.org/10.1007/978-3-030-38246-9_12
}

211 
debate has focused on the passion creative workers have for their jobs and thus on the emotional investment in their careers, on the one hand, and on the lack of rights and collective representation they experience, on the other (Gill 2002; McRobbie 2002; de Peuter and Dyer-Witheford 2006; Jarvis and Pratt 2006; Hesmondhalgh and Baker 2008; Morgan and Nelligan 2015; Taylor and Luckman 2018). However, the debate on the new forms of collective organisation that can be developed to counteract the ongoing process of hyper-individualisation is still largely overlooked in sociological perspectives on contemporary creative work (Gill and Pratt 2008).

In this contribution we discuss the case of the Société Mutuelle pour artistes (Smart), a freelancers' cooperative that developed a novel model to empower freelance creative workers-both commercially and sociallyin the attempt to support their careers and to create new forms of solidarity, despite the general trend of a lack of social protection rights and collective representation for the self-employed (Graceffa and de Heusch 2017). Established in Belgium in 1998 as a non-profit organisation supporting only freelance artists, nowadays, Smart is a cooperative of freelancers active in nine European countries. Over the years Smart has realised that in most European countries, as well as in other industrialised markets, the situation of artists is in many ways no different from that of creative workers and more generally of most freelancers, who work in a wide range of economic sectors. They range from consultants, IT developers and trainers to caterers, web designers and riders for food delivery platforms.

This chapter is structured as follows. First, we discuss the process of individualisation experienced by creative workers, how these pathways are affecting the entire labour market, and the emerging attempts to cast this ambivalent process into new forms of collective organisation, paying specific attention to the cooperative model. Second, we introduce the case study and the methodological approach. Finally, we present the empirical section, which illustrates, through the case of Smart, how a cooperative model can enact new forms of autonomy and solidarity, and the importance of a transnational network able to support freelancers beyond specific national contexts. In the conclusion, we discuss the urgency of developing a new compositional project that is able to meet the needs and aspirations of freelance creative workers as well as those of all workers whose career pathways are affected by the ongoing processes of individualisation and fragmentation. 


\section{'Collectively Individualised': On the InCRease of Fragmentation, But Also the Emerging Attempts at Collective Organisation}

In the past, much academic attention has been directed to the processes of fragmentation and individualisation in the creative and cultural sectors (McRobbie 2002; Banks and Hesmondhalgh 2009). Creative workers, in fact, have always epitomised what Honneth (2004) has defined as the 'paradox of individualization': on the one hand, they enjoy freedom and do a job they love; on the other, they are also exposed to multiple risks of precariousness and uncertainty. In fact, despite often being employed in short-term and low-paid jobs on an insecure or freelance basis (Gill and Pratt 2008; Taylor 2010), they are motivated by the promise of selfrealisation and the destandardisation of work contents and forms (Gherardi and Murgia 2013; Bascetta 2015).

Today, however, there is widespread recognition that work in general is affected by profound transformations that are no longer unique to the dynamics typical of creative work. Firstly, the transformation of every individual into a 'self-entrepreneurial' subject (Foucault 1979/2008) has become a global project that requires everyone to have an individual mission of self-realisation (du Gay 1997; Rose 1999), based mainly on the self-promotion of subjective resources (Corsani and Lazzarato 2008; Raunig et al. 2011). Secondly, the aspiration of achieving creative fulfilment and escaping from the nine-to-five organisation of work does not only attract aspirants to creative work, but it is more and more an intrinsic property of the new model of capitalism (Boltanski and Chiapello 1999; Neilson and Rossiter 2005). Finally, creative workers have specific characteristics, but are at the same time part of a renewed 'geography of work' (Ross 2008), and share elements of precarious and non-standard employment such as income instability, an erratic work schedule, the blurred boundaries between work and non-work times and spaces, the promise of a symbolic recognition, and the absence of collective representation (see Armano et al. 2017).

Beyond identifying the commonalities between creative workers' trajectories and other professional careers, nowadays the main challenge is to identify the main cross-cutting axes of potential recomposition in such a fragmented labour market and to understand how to build solidarity in difference across diverse sectors and how to implement a wider process of 
political recomposition (Gill and Pratt 2008; Ross 2008; de Peuter 2011; Armano and Murgia 2017).

Over the past two decades, many collective organisations have been created to counter the processes of individualisation and fragmentation of work in creative work and beyond (Hyman and Gumbrell-McCormick 2017; Bologna 2018). The constant increase in numbers of freelancers and solo self-employed workers (Eurofound 2017), in fact, requires solutions that are able to build solidarity between workers whose career pathways and lives are more and more individualised-workers who do not have access to the main forms of social protection and often work for several clients, but do not want to renounce their autonomy (Luckman 2014; Taylor and Luckman 2018). An example is the rapid emergence of new labour market intermediaries (LMI), aiming to support these novel career structures and to challenge the existing paradigms that are used to regulate labour markets (Bonet et al. 2013; Lorquet et al. 2017). These processes are changing the traditional configuration between client, employer and worker (Havard et al. 2009), which is becoming more complex as workers are required to assume obligations to multiple parties (Marsden 2004; Ashford et al. 2007; Cappelli and Keller 2013) and responsibility is diluted amongst the three different actors (LMI, client and worker).

Among emerging organisational alternatives and multiple employment relations, cooperatives have been rediscovered as an option for promoting solidarity despite the new challenges in contemporary labour market pathways (Cheney et al. 2014; Perotin 2014). Indeed, as has been recently pointed out,

Worker cooperatives are among the organizational models emerging as a response to these new forms of work with deficits in legal and social protection and substandard working conditions. They are enterprises run and managed by and for the workers who own the capital, vote as equal members on matters related to running the business and have the right to stand in for elections of the Board of Directors. (Esim and Katajamaki 2017, p. 3)

Like mutual benefit societies and social enterprises and associations, the worker cooperative represents a form of economic organisation that is part of the social and solidarity economy (Restakis 2010; Webb and Cheney 2014). However, as with other organisational models, its effect can be ambivalent. It can implement alternative forms of governance and 
represent one response to insecurity in the labour market, mainly by supporting new forms of work, with less dependence on the employer and more autonomy and collaboration among workers (Pencavel 2013; Parker et al. 2014). At the same time, it can also reproduce the capitalist system and be associated with enabling worse working conditions and reduced social security coverage than is available for employees with standard work arrangements (Paranque and Willmott 2014; International Labour Office 2016). Analysis of worker cooperatives whose members are freelance creative workers is still scarce. The present contribution aims to fill this gap by advancing knowledge about how cooperatives are experimenting with employment relations built on alternative organisational models and challenging the individualisation of the labour market.

Among freelance cooperatives, there are (1) those composed of workers with a self-employed legal status and (2) those that provide workers with the more protective status of employee, while allowing them to keep their autonomy and to control the labour process. In this chapter the focus is on the latter case, namely a cooperative in Europe that employs freelancers as salaried workers, but at the same time allows them to work as freely as self-employed workers. Accordingly, we define our case study as a cooperative of 'salaried autonomous workers' as it would not be legally correct to use the category 'self-employed workers' because of the employee status of the cooperative members. More specifically, we focus on Smart, a cooperative currently composed of workers belonging to extremely varied sectors and occupations, but with origins in creative work. Initially composed only of artists, it was then opened up to creative workers, and today it welcomes workers from sectors that are very diverse from each other, from media, entertaining and training, to riders delivering restaurant food and working for platform companies. Before moving to the findings, we describe the case study and the methods and data used in this research.

\section{Research CONTEXT}

Smart is a cooperative of freelancers active in nine European countries. It was created in Belgium in 1998 as a non-profit organisation that supports artists. Since then, more than 100,000 people across Europe have operated from within Smart, and in 2018 alone members invoiced more than 200 million euros (Smart 2019). Smart considers itself a 'shared enterprise', a shared production tool that is altogether the means and the 
service for and of freelancers. Unlike most workers' cooperatives, Smart members are not working to develop a product or service through the cooperative; in Smart's case, the cooperative is the production infrastructure that allows freelancers to each produce their own product or service that they sell independently. Except for the 6.5-9.0\% levy (following the countries) that goes to the cooperative, the income generated by this activity benefits the worker-producer directly. In fact, the cooperative's economic model is based on the pooling of means financed by this levy: each revenue from each activity finances up to $6.5 \%$ of the mutualised services regardless of the services used or the volume of business generated by the freelancer. Thanks to this mutualisation of means, over the years Smart has been able to provide a range of services that support freelancers in the development of their activities (information, trainings, legal advice, insurances, working spaces, a salary guarantee fund and a social professional network), including mutualisation of economic risks that are borne by the cooperative rather than by the individuals. All the benefits generated by Smart are in fact mutualised and reinjected into the enhancement of existing or the development of new services.

This way of reinventing the workers' cooperative model through the shared enterprise is enabled by the cooperative's objective of providing the means for freelancers to develop their own economic activities autonomously while generating socialised and taxed income. In fact, this allows a double form of solidarity: the one linked to the mutualisation of means and the one linked to the salaried status. Smart provides freelancers with the status of salaried worker because this is the employment status that, in most European countries, allows access to the best social protection. This means that the cooperative takes on the role of employer for the length of the contract. The length of the contract and level of income generated depend on what the freelancer was able to negotiate (as a producer or economic agent), taking into account a certain number of minimal rules set by Smart (as the employer): a minimum hourly wage and a minimum length of contracts. With this model the freelance, as a salaried worker, is covered by collective bargaining rules and as an entrepreneur is autonomous without running the risk of going bankrupt, having to deal only with work revenue and expenses, the salary negotiated being paid by Smart in any case through the salary guarantee fund (regardless of when and if the client pays Smart). The cost and burden of running a business are therefore covered by the cooperative. 
The Smart case is exemplary of how the artistic sector's specificities have paved the way for other forms of increasingly precarious and contract-based work that are spreading rapidly both in absolute numbers and in range of activities. In fact, by developing solutions for artists, Smart actually developed services that could be adapted to freelancers broadly, generating possibilities for solidarity and cross-connection across industry sectors. Furthermore, the open recruitment policy, together with the use of a digital platform, provided Smart with a unique view on this emerging category of workers, whose reality is rarely acknowledged because they are treated either on the basis of their legal status (mainly self-employed) or on the basis of their professions (e.g. artists, musicians, translators and IT consultants). This broader approach to individualised flexible career pathways in this segment of the labour market forces us to rethink our social security systems through the lenses of those who are autonomous in many respects, but who also need social protection and collective representation.

\section{Methodology}

Methodologically, the research described in this chapter is based on an empirical qualitative inquiry undertaken as a process of co-research, a form of inquiry that challenges the division between the subject-researcher and object-researched (Alquati 1993; de Molina 2004). Doing co-research means creating a collective space where experiences can foster critical consciousness about commonsensical praxis, therefore enabling a mutual sense of agency. The practice of co-researching was born in Italy in the early 1960s (the main example is the editorial collective of Quaderni Rossi, see Bologna 2014) as a militant research with factory workers, with the aim of producing a collective knowledge requiring a greater capacity of reflection and action. It is therefore an activity that allows the creation of horizontal encounters between the researchers and a specific group of workers, and the opening up of new imaginaries and political possibilities to be built together. In our case, this chapter was written by an academic researcher and a person employed by Smart, with a privileged position in the cooperative since she deals mainly with developing knowledge and partnerships with other organisations (networks and NGOs, as well as universities and research centres).

In terms of presentation of our empirical material, we discuss the interviews and the conversations we had (and that are still in progress) in Smart Belgium and in Smart sites in other European countries, which are 
characterised by different welfare systems and substantial differences in the ways they manage freelancers. In addition, a range of organisational documents have been included in the analysis. ${ }^{1}$ In presenting our main findings, we discuss how the cooperative is able to maintain both autonomy and solidarity. Firstly, it does this by addressing no longer just the artists, and not just the creative workers, but all the freelancers. Secondly, Smart is building a European network to support freelancers and is also planning to expand it internationally. In fact, the situation of freelancers, while having specific national characteristics, has common characteristics at a global level.

The analysis of this case study allows us to do two things. Firstly, we highlight how the conditions of creative workers have their own specificities but are at the same time characterised by elements that distinguish many jobs within the current individualised and 'find-out-for-yourself' societies. Secondly, we contribute to the debate that, for more than 20 years, has been discussing whether, under conditions of individualisation, new collective forms of action can take shape, and, if so, which forms they might take (see Beck and Beck-Gernsheim 1996, 2002).

\section{How to Bridge Autonomy and Solidarity: The Case OF SMART}

\section{From Artists to Creative Workers to All Freelancers}

Smart is a cooperative of freelancers active in nine European countries that began in 1998 as a Belgian non-profit organisation supporting artists. The story of the cooperative is illustrative of the labour market evolution, and especially of a very specific and fast-growing category of workers: freelancers. When Smart started out, it was meant to support freelance artists in the management of their activities. These workers (who were taught art in school, but not necessarily how to live from their art) deal with short-term contracts, multiple clients, changing teams, changing roles (sometimes leading projects, sometimes working for others' projects) and often

\footnotetext{
${ }^{1}$ Fieldwork activities were conducted in Belgium, France, Germany, Italy and the Netherlands, within the project Seizing the Hybrid Areas of work by Re-presenting selfEmployment (SHARE) (2018), which has received funding from the European Research Council (ERC) under the European Union's Horizon 2020 research and innovation programme (grant agreement N. 715950).
} 
professional geographic mobility. Furthermore, to make a living, they often perform multiple jobs they develop from their primary skills. This makes the legal and administrative environment of their work quite complex to deal with, especially as they have to juggle different rules for each of the jobs (e.g. a musician who is teaching is not bound by the same legal and fiscal prerequisites as when playing) as well as the jobs themselves. Smart's mission has always been to simplify legal and administrative issues to enable these workers to focus on their work and finding clients.

Quite quickly, Smart opened up to creative professionals more broadly, firstly, because the jobs developed by artists to make ends meet are often in the creative sector (mainly skills linked to their artistic activities, such as teaching, or linked to the production and dissemination of their work, such as management, communications and budgeting), but also because in order to support artists, it is important to support their wider ecosystem (e.g. managers, technicians and bookers). Therefore, the creative sector was understood in a broad sense that included not only graphic designers and fashion design but also professions such as journalism and translation.

Pathways into and through creative work are rarely neat and selfcontained; the creative sector covers a broad range of jobs, and since many of these professionals are 'slashers' (professionals who undertake multiple jobs, i.e. journalist/writer/trainer), Smart also dealt with the non-creative activities of its members. As Smart came to be known outside its original sectors of activity, demand from other professionals from the service economy grew steadily. Initially, the organisation did not know how to deal with people that do not work in the creative sector at all. Was Smart supposed to open up? Smart's primary fear was losing its purpose and capacity to lobby-who would it represent? After a few years of indecision, when the organisation was transforming into a cooperative, it put into place participatory governance and organised a working group on the topic. Smart members and employees unanimously agreed that the cooperative should open up to all who need it. As a counterpart, an ethical committee was formed to set boundaries and ensure it remained a responsible employer. This is when Smart decided to welcome all freelancers, or what it calls 'autonomous workers'.

As of end of 2018, Smart in Belgium has over 20,000 shareholders and 35,000 users from very diverse sectors of activity, ranging from training to catering, from handcraft to consultants and from well-being coaches to delivery riders (Smart 2019). This variety of worker profiles has proven to Smart that the distinction between high- or low-skill requirements is 
immaterial to distinguishing freelancers. In fact, some highly skilled workers have decided to convert to manual work and vice versa, and manual jobs require skills that are only developed through experience, which becomes expertise. As to income levels, jobs requiring a high level of skills do not necessarily pay as much but may be symbolically gratifying.

If Smart has a unique overview of sectors of activities and income generated by freelancers within the shared enterprise, there can also be no holistic view of the overall activities and income of its members, because there is no binding relationship between Smart and its members. Some members invoice everything through the cooperative; others can also enjoy retirement or unemployment benefits when they do not work or even count on income from another job (part-time or full-time). In this way, Smart members are very diverse, and it is impossible to draw a prototypical portrait of an 'average member'.

\section{From a Labour Market Intermediary to a 'Quasi-union'}

From the very beginning of Smart, the main objective has been to provide solidarity and support to autonomous workers, and that is where its originality and innovation stems from. From the get-go, the idea was to provide a double solidarity to freelancers: the one linked to the most protective working status (the one of salaried worker), and the other one provided by the mutualisation of means, as encapsulated in its very name-Société Mutuelle pour artistes. As a mutual society, all the benefits are redistributed to members through the development of services and tools. The extent of mutualised services developed along the years is linked to the automation of procedures, which quickly became an integral part of the Smart services. In fact, the founders quickly realised that they were 'wasting' a lot of time in repetitive tasks (such as the identification of appropriate levels of taxes and social contributions). In order to free time for advising members on their activity, they decided to computerise the contracting and invoicing process. The idea is for members to answer very simple questions (such as 'What is the task to be done?', 'How much are you paid?', 'Where are you working?') and from these simple questions, the platform's software identifies and calculates the appropriate fiscal and social contributions. Once the contracts are signed by both the freelancer and the client, and validated by Smart, the cooperative pays all taxes and social contributions to relevant authorities and pays net income to the member. Smart also 
undertakes all the formalities linked to work (providing declaration of work to the authorities and all necessary documentation to the worker).

This automation process allowed the cooperative to service hundreds, then thousands of freelancers daily, which in return allowed the generation of an increasing volume of benefits. Over the years, Smart-especially in Belgium - has been able to develop the following: a salary guarantee fund to pay members within seven working days, insurances (accident at work, extended to private life, mobility and civil liability), advice, mediation, training, research and knowledge on freelancers, co-working spaces, and meet and connect opportunities. Each of these services is intended to support members in the development of their professional activities, providing the flexibility they need. In fact, for Smart, autonomy should not imply isolation or even precariousness, and mutualisation is seen as the best way to create solidarity for these workers.

While Smart considers itself a shared enterprise at its members' service, many observers have also identified it as a 'quasi-union' because of the advocacy activities it has developed as well as the actions it has undertaken for food delivery riders (from Take Eat Easy and Deliveroo) (see Vandaele 2018; Xhauflair et al. 2018). Because of the automation of processes, in fact, Smart is not always aware of its members' clients. It came to a surprise when hundreds of members had a single client. This happened with both Take Eat Easy and Deliveroo, with whom contracts were problematic. Therefore, Smart gathered these workers together and tried to understand how those clients worked. Because their functioning was incompatible with the prerequisites of Smart as employer (such as a minimum of three consecutive hours of work and a minimum hourly wage), the cooperative decided to negotiate with the food delivery platforms. It managed to settle payment by the hour (instead of by the delivery), with minimum threehour shifts, a defined hourly wage (instead of calculation by algorithm), reimbursement of the use of tools (bike and cell phone), and safety and security training before first delivery. The riders then accessed Smart's insurances (accident at work and civil liability). Many observers consider Smart assumed the role of union in this case, in a peculiar configuration, as it was a commercial agreement undertaken on behalf of workers with a company. It was also the only such commercial agreement Smart has undertaken.

Beyond this specific action, the cooperative has also undertaken advocacy actions for autonomous workers (first creative professionals and now cross-sectorally). The reason an organisation that considers itself to be a 
service developed advocacy lines is that it did not find a voice in social dialogue institutions, such as unions and employer associations, which echoed the need to bridge autonomy and solidarity. This is essentially because of how the social dialogue is conceived: the dichotomy between subordinate employees (who need social protection) and employers (who take risks and are autonomous). However, a vast majority of freelancers consider themselves to be neither of these (Murgia and Pulignano 2019). In fact, in the Smart community, many freelancers are different from classic liberal professionals (both in the sectors of activities and in the average levels of income); they are autonomous in many respects, but they also ask for social protection, as demonstrated by the main findings of the European project I-Wire (see Beuker et al. 2017). Even though political authorities and social dialogue representatives are beginning to acknowledge this reality, representation of these workers and their views is still lacking. Unions are starting to understand the interests of freelancers and wish to reach out to them as well, but this enlargement requires quite a change of perspectives and functioning.

\section{From Nationally to Internationally Based Projects and Networks}

Another aspect that pushed Smart to open up to all freelancers was the internationalisation of its activities. Quite naturally, the first country into which Smart expanded was France, for the simple reason that a majority of Belgian members who had an international activity went to France (for linguistic reasons and because it is a neighbouring country). Therefore, Smart had many contacts in France and, quite naturally, partnerships were built with local social entrepreneurs to set up a sister organisation. Just as services were launched in France, contacts were also made with cultural professionals in other countries. Smart was invited by the French community of Belgium to participate in the Open Method of Coordination of the European Union on the mobility of artists and cultural professionals. At this occasion, Smart met many representatives of the cultural sector and started to be active in major cultural networks. These were all opportunities to learn about different legal, cultural and economic realities. Discussions about freelance creatives with cultural professionals revealed similar global trends, which were not necessarily linked to their legal status (salaried or self-employed), but to the way they work. What made them 
need to be both autonomous and able to access social protection was the irregularity of income, the multiplicity of clients, the multi-activity and the juggling with different statuses. Because of the shared business models that operate in different occupational and geographical areas, and despite the different effects of locality (national and local) and systems of regulation, the Smart model was adaptable to different realities.

Having to deal with the different realities of creative professionals (as an example, in France performing artists are mandatorily considered salaried workers, whereas in Germany they are self-employed with specific social security advantages), Smart realised that what it provided was not simply solutions for creative professionals but, more broadly, solutions for freelancers. This also convinced the organisation to embrace all freelancers rather than only those from the creative sector. The internationalisation of Smart activities also revealed that the most appropriate legal structure for the economic model developed was not the non-profit organisation initially adopted, but the cooperative. Firstly, the cooperative model allows for rationalisation of the different roles the freelancers take within Smart: they are at the same time co-owners (shareholders), entrepreneurs (as they have to find work opportunities and negotiate conditions) and workers (as the freelancers actually 'get the job done' as salaried workers of the organisation). Secondly, the shared enterprise-the cooperative-is both the production tool and the service.

Furthermore, internationalisation was not only an opportunity to rethink the initial organisational model (transforming into a cooperative and opening up to freelancers); it also helped legitimise the project both in Smart's country of origin and at a wider European level. In fact, it is one of the first and rare entities to have envisaged freelancers as a category per se (beyond the legal status or sector of activity), to work transnationally and to promote a model that allies autonomy and solidarity. This innovative approach is recognised by the European Commission through invitations to speak on the future of work or at hearings on the European Pillar of Social Rights (European Commission 2017), ${ }^{2}$ as well as by recent awards such the one given by the European Commission Joint Research Council as best proven impact for social innovation and the Royal Society for the Arts Future of Work Award.

\footnotetext{
${ }^{2}$ Hearings are considered essential to the work of European institutions because they provide the opportunity to hear from experts and to discuss key issues.
} 


\section{Conclusions: A Constantly Evolving Cooperative in a Constantly Evolving Labour Market}

In the new pathways underpinning contemporary employment and careers, worker cooperatives have been considered mainly as a means of supporting fragmented professional trajectories and individualised workers while giving them more voice in setting their wages and working conditions (Conaty et al. 2016). In recent years, freelance cooperatives have spread significantly in the Global South and are also increasing in the Global North. In India, the Self-employed Women's Association counts almost two million members (Dave and Arora 2015). In North America, the Tech Co-op Network, which collaborates closely with the Freelancers Union, is composed of worker cooperatives that provide media, communications and computer technology goods and services in the US, Canada, Mexico, Central America and the Caribbean. In Europe, one of the most outstanding examples of worker cooperatives to date is the Mondragon Cooperative Group. Comprising 289 institutions, of which 110 are cooperatives, its members can be both self-employed and employees according to the organisational model implemented in the different cooperatives (Flecha and Ngai 2014; Bretos and Errasti 2017). In fact, as already mentioned, in the heterogeneous world of cooperatives dealing with freelancers, there are both cooperatives of self-employed individuals and cooperatives that opt to assign the status of employee to their members, although they allow them to maintain the autonomy typical of selfemployment. As for the latter, in the European context, several interesting examples were developed during the 1990s. One is Smart, the cooperative at the centre of this study. Another is the French Coopératives d'Activités et d'Emploi (Business and Employment Cooperatives), whose members run a business that generates revenue, while are employed by the cooperative and become 'salaried entrepreneurs' (Bureau and Corsani 2017).

In our view, Smart is a promising laboratory for a recomposition of labour politics, which started with artists and creative work and then extended to the entire heterogeneous world of freelancers across different European countries. However, in order to support the careers of people with experiences very distant from the Fordist era-in terms of both working conditions and aspirations-it is necessary to analyse also how the labour market is regulated and industrial relations regimes structured. Even if national labour market reforms do not seem to widen but rather limit access to forms of social protection, the European Commission is 
exploring ways of providing as many workers as possible with social security cover, regardless of the sector and the type of employment contract. In particular, the European Pillar of Social Rights, signed in November 2017 by the Council of the European Union, the European Parliament and the Commission, is structured around the three principles of equal opportunities and access to the labour market, fair working conditions, and social protection and inclusion. The agreement aims to protect workers, including self-employed and platform workers. Although making social issues a high political priority is a step in the right direction, it is nevertheless a missed opportunity. Except for a few topics that will be entrenched in directives (such as the work-life balance challenges faced by working parents and carers, and the revision of the Written Statement Directive 91/533/EEC [European Commission n.d.] to introduce minimum standards applicable to every employment relation), most of the points of the European Pillar of Social Rights are likely to become simply recommendations. This will hinder its capacity to influence the member states' decisions on the protection of workers and more generally of people living in the European Union. It is in this context, as we start rethinking the social protections that are applicable to those whose career pathways lie outside the Fordist system, that cases like Smart are extremely interesting and very important. At the same time, broader policy proposals and institutional innovations are increasingly urgent for mitigating the fragmentation and the individualisation of work within and beyond creative economy sectors.

\section{REFERENCES}

Alquati, R. (1993). Per fare conricerca. Milano: Calusca Edizioni.

Armano, A., \& Murgia, A. (2017). Hybrid areas of work in Italy. In E. Armano, A. Bove, \& A. Murgia (Eds.), Mapping precariousness: Labour insecurity and uncertain livelihoods. London: Routledge.

Armano, E., Bove, A., \& Murgia, A. (Eds.). (2017). Mapping precariousness: Labour insecurity and uncertain livelihoods. London: Routledge.

Ashford, S. J., George, E., \& Blatt, R. (2007). Old assumptions, new work: The opportunities and challenges of research on nonstandard employment. Academy of Management Annals, 1(1), 65-117.

Banks, M., \& Hesmondhalgh, D. (2009). Looking for work in creative industries policy. International Journal of Cultural Policy, 15(4), 415-430.

Bascetta, M. (Ed.). (2015). L'economia della promessa. Roma: Manifestolibri. Bauman, Z. (2000). Liquid modernity. Cambridge, UK: Polity Press. 
Beck, U. (1992). Risk society: Towards a new modernity. London and New York: SAGE. Beck, U., \& Beck-Gernsheim, E. (1996). Individualization and 'precarious freedoms': Perspectives and controversies of a subject-oriented sociology. In P. Helas, S. Lash, \& P. Morris (Eds.), Detraditionalisation: Critical reflections on authority and identity (pp. 23-48). Cambridge: Blackwell.

Beck, U., \& Beck-Gernsheim, E. (2002). Individualization: Institutionalized individualism and its social and political consequences. London: Sage.

Beuker, L., Naedenoen, F., \& Pichault, F. (2017). Belgian country case study. WP3. Country case studies. Retrieved from https://i-wire.eu/wp-content/ uploads/2018/04/I-WIRE-WP3_D3.1_country-case_Belgium_Vfin.pdf.

Bologna, S. (2014). Workerism: An inside view from the mass-worker to selfemployed labour. In M. van der Linden \& K. Heinz Roth (Eds.), Beyond Marx: Theorising the global labour relations of the twenty-first century. Leiden and Boston: Brill.

Bologna, S. (2018). The rise of the European self-employed workforce. Milano: Mimesis. Boltanski, L., \& Chiapello, E. (1999). Le nouvel esprit du capitalisme. Paris: Gallimard.

Bonet, R., Cappelli, P., \& Hamori, M. (2013). Labor market intermediaries and the new paradigm for human resources. Academy of Management Annals, $7(1), 341-392$.

Bretos, I., \& Errasti, A. (2017). Challenges and opportunities for the regeneration of multinational worker cooperatives: Lessons from the Mondragon Corporation - a case study of the Fagor Ederlan Group. Organization, 24(2), 154-173.

Bureau, M.-C., \& Corsani, A. (2017). The French business and employment cooperative. An autonomy factory? In E. Armano, A. Bove, \& A. Murgia (Eds.), Mapping precariousness: Labour insecurity and uncertain liveliboods (pp. 60-69). London: Routledge.

Cappelli, P., \& Keller, J. R. (2013). Classifying work in the new economy. Academy of Management Review, 38(4), 575-596.

Cheney, G., Santa Cruz, I., Peredo, A. M., \& Nazareno, E. (2014). Worker cooperatives as an organizational alternative: Challenges, achievements and promise in business governance and ownership. Organization, 21(5), 591-603.

Conaty, P., Bird, A., \& Ross, P. (2016). Not alone: Trade union and cooperative solutions for self-employed workers. Manchester: Co-operatives UK. Retrieved August 7, 2019, from http://www.uk.coop/notalone.

Corsani, A., \& Lazzarato, M. (2008). Intermittents et précaires. Paris: Éditions Amsterdam.

Dave, J., \& Arora, K. (2015). Interventions by the Self Employed Women's Association (SEWA) in Ahmedabad, India. Inclusive Cities Project, October. Women in Informal Employment: Globalizing and Organizing. Retrieved 
October 4, 2019, from http://www.inclusivecities.org/wp-content/ uploads/2015/11/IC-Ahmedabad-Case-Study.pdf.

Esim, S., \& Katajamaki, W. (2017). Rediscovering worker cooperatives in a changing world. IusLabor, 1, 1-8.

Eurofound. (2017). Exploring self-employment in the European Union. Luxembourg: Publications Office of the European Union.

European Commission. (2017). European pillar of social rights. Publications Office of the European Union. Retrieved October 4, 2019, from https:// ec.europa.eu/commission/sites/beta-political/files/social-summit-europeanpillar-social-rights-booklet_en.pdf.

European Commission. (n.d.). Working conditions - individual employment conditions - written statement. Employment, Social Affairs \& Inclusion, European Commission. Retrieved October 7, 2019, from https://ec.europa.eu/social/ main.jsp? catId=706\&langId=en\&intPage $I d=202$.

Flecha, R., \& Ngai, P. (2014). The challenge for Mondragon: Searching for the cooperative values in times of internationalization. Organization, 21(5), 666-682.

Foucault, M. (1979/2008). The birth of biopolitics: Lectures at the College de France 1978-1979 (G. Burchell, Trans. \& M. Senellart, Ed.). Basingstoke: Palgrave Macmillan.

du Gay, P. (1997). Organizing identity: Making up people at work. In P. du Gay (Ed.), Production of culture/cultures of production (pp. 285-344). London: SAGE.

Gherardi, S., \& Murgia, A. (2013). By hook or by crook: Flexible workers between exploration and exploitation. Research in the Sociology of Organization, $37,75-103$.

Gill, R. C. (2002). Cool, creative and egalitarian? Exploring gender in projectbased new media work in Europe. Information, Communication \& Society, 5(1), 70-89.

Gill, R., \& Pratt, A. (2008). In the social factory? Immaterial labour, precariousness and cultural work. Theory, Culture \& Society, 25(7-8), 1-30.

Graceffa, S., \& de Heusch, S. (2017). Reinventing the world of work. Transfer, $23(3), 359-365$.

Havard, C., Rorive, B., \& Sobczak, A. (2009). Client, employer and employee: Mapping a complex triangulation. European Journal of Industrial Relations, 15(3), 257-276.

Hesmondhalgh, D., \& Baker, S. (2008). Creative work and emotional labour in the television industry. Theory, Culture \& Society, 25(7-8), 97-118.

Honneth, A. (2004). Organized self-realization: Some paradoxes of individualization. European Journal of Social Theory, 7(4), 463-478.

Hyman, R., \& Gumbrell-McCormick, R. (2017). Resisting labour market insecurity: Old and new actors, rivals or allies? Journal of Industrial Relations, $59(4), 538-561$. 
International Labour Office. (2016). A challenging future for the employment relationship: Time for affirmation or alternatives? The Future of Work Centenary Initiative Issue Note Series No. 3. International Labour Office. Retrieved October 4, 2019, from https://www.ilo.org/global/topics/future-of-work/ WCMS_534115/lang\%2D\%2Den/index.htm.

Jarvis, H., \& Pratt, A. C. (2006). Bringing it all back home: The extensification and 'overflowing' of work: the case of San Francisco's new media households. Geoforum, 37(3), 331-339.

Lorquet, N., Orianne, J. F., \& Pichault, F. (2017). Who takes care of non-standard career paths? The role of labour market intermediaries. European Journal of Industrial Relations, 24(3), 279-295.

Luckman, S. (2014). Precarious labour then and now: The British arts and crafts movement and cultural work revisited. In M. Banks, R. Gill, \& S. Taylor (Eds.), Theorizing cultural work: Labour, continuity and change in the cultural and creative industries. London and New York: Routledge.

Marsden, D. W. (2004). The 'network economy' and models of the employment contract. British Journal of Industrial Relations, 42, 659-684.

McRobbie, A. (2002). Clubs to companies: Notes on the decline of political culture in speeded up creative worlds. Cultural Studies, 16(4), 516-531.

de Molina, M. M. (2004). Common notions part 1. Workers inquiry, co-research, consciousness-raising (M. Casas-Cortés \& S. Cobarrubias, Trans.). European Institute for Progressive Cultural Politics. Retrieved August 7, 2019, from http://strickdistro.org/wp-content/uploads/2012/09/Reading-16-Oct_ Malo-De-Molina-2004.pdf.

Morgan, G., \& Nelligan, P. (2015). Labile labour-gender, flexibility and creative work. The Sociological Review, 63(SI), 66-83.

Murgia, A., \& Pulignano, V. (2019). Neither precarious nor entrepreneur: The subjective experience of hybrid self-employed workers. Economic and Industrial Democracy, 0143831X19873966.

Neilson, B., \& Rossiter, N. (2005). FCJ-022 From precarity to precariousness and back again: Labour, life and unstable networks. Fibreculture Journal, 5. Accessed August 7, 2019, from http://five.fibreculturejournal.org/fcj-022from-precarity-to-precariousness-and-back-again-labour-life-and-unstablenetworks/.

Paranque, B., \& Willmott, H. (2014). Cooperatives - saviours or gravediggers of capitalism? Critical performativity and the John Lewis Partnership. Organization, 21(5), 604-625.

Parker, M., Cheney, G., Fournier, V., \& Land, C. (2014). Introduction. In M. Parker, G. Cheney, V. Fournier, \& C. Land (Eds.), The Routledge companion to alternative organization (pp. 1-41). London: Routledge.

Pencavel, J. H. (Ed.). (2013). The economics of worker cooperatives. Cheltenham: Edward Elgar Publishing. 
Perotin, V. (2014). What do we really know about worker co-operatives? Manchester: Co-operatives UK.

de Peuter, G. (2011). Creative economy and labor precarity: A contested convergence. Journal of Communication Inquiry, 35(4), 417-425.

de Peuter, G., \& Dyer-Witheford, N. (2006). A playful multitude? Mobilising and counter-mobilising immaterial game labour. Fibreculture, 5. Retrieved August 7, 2019, from http://five.fibreculturejournal.org/fcj-024-a-playful-multitude-mobilising-and-counter-mobilising-immaterial-game-labour/.

Raunig, G., Ray, G., \& Wuggenig, U. (Eds.). (2011). Critique of creativity: Precarity, subjectivity and resistance in the 'creative industries'. London: Mayfly.

Restakis, J. (2010). Humanizing the economy: Co-operatives in the age of capital. Gabriola Island: New Society Publishers.

Rose, N. (1999). Governing the soul: The shaping of the private self. London: Free Association Books.

Ross, A. (2008). The new geography of work: Power to the precarious? Theory, Culture \& Society, 25(7-8), 31-49.

Sennett, R. (1998). The corrosion of character: The personal consequences of work in the new capitalism. London: Norton.

SHARE - Seizing the Hybrid Areas of Work by Re-presenting Self-Employment. (2018). Department of Social and Political Sciences, Università degli Studi di Milano. Retrieved April 30, 2020, from https://sites.unimi.it/erc_share/.

Smart. (2019). Rapport d'activité 2018 PERSPECTIVES 2019 Belgique France. Brussels: Smart. Retrieved October 3, 2019, from https://smartbe.be/wpcontent/uploads/2019/06/Rapport-dactivite-Smart-2018.pdf.

Taylor, S. (2010). Negotiating oppositions and uncertainties: Gendered conflicts in creative identity work. Feminism \& Psychology, 21(3), 354-371.

Taylor, S., \& Luckman, S. (Eds.). (2018). The new normal of working lives: Critical studies in contemporary work and employment. London: Palgrave Macmillan.

Vandaele, K. (2018). Will trade unions survive in the platform economy? Emerging patterns of platform workers' collective voice and representation in Europe. Working Paper 2018.05, Brussels: European Trade Union Institute.

Webb, T., \& Cheney, G. (2014). Worker-owned-and-governed cooperatives and the wider cooperative movement: Challenges and opportunities within and beyond the global economic crisis. In M. Parker, G. Cheney, V. Fournier, \& C. Land (Eds.), The Routledge companion to alternative organization (pp. 64-88). London: Routledge.

Xhauflair, V., Huybrechts, B., \& Pichault, F. (2018). How can new players establish themselves in highly institutionalized labour markets? A Belgian case study in the area of project-based work. British Journal of Industrial Relations, $56(2), 370-394$. 
Open Access This chapter is licensed under the terms of the Creative Commons Attribution 4.0 International License (http://creativecommons.org/licenses/ by $/ 4.0 /$ ), which permits use, sharing, adaptation, distribution and reproduction in any medium or format, as long as you give appropriate credit to the original author(s) and the source, provide a link to the Creative Commons licence and indicate if changes were made.

The images or other third party material in this chapter are included in the chapter's Creative Commons licence, unless indicated otherwise in a credit line to the material. If material is not included in the chapter's Creative Commons licence and your intended use is not permitted by statutory regulation or exceeds the permitted use, you will need to obtain permission directly from the copyright holder.

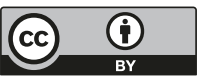

